\title{
Multimedia Innovation 4.0 in Education: E-Modul Ethnoconstructivism
}

\author{
Asrial, Syahrial", Dwi Agus Kurniawan, Faizal Chan, Retno Septianingsih, Rahmat Perdana \\ Faculty of Teaching and Education, Universitas Jambi, Indonesia
}

Received August 2, 2019; Revised August 30, 2019; Accepted September 15, 2019

Copyright $\odot 2019$ by authors, all rights reserved. Authors agree that this article remains permanently open access under the terms of the Creative Commons Attribution License 4.0 International License

\begin{abstract}
This paper presents educational innovation for the learning of ethno-constructivism-based e-modules using 3D page flip. Ethnoconstructivism-based E-modules use 3D page flip, are made of stages of development, implementation, and evaluation adopted from the branch. The purpose of responding to ethnoconstructivism-based e-module implementations using 3D page flip and after using e-modules from ethnoconstructivism-based e-module implementations using 3D page flip. On the respond results for the control class that uses conventional, there are significant differences with the experimental class using ethnoconstructivsm-based e-modules using 3D page flip, which is in the superior experimental class because it uses ethnoconstructivsm-based e-modules using flip 3D pages flip with t-test values amounting to 18.342 .
\end{abstract}

Keywords Multimedia, Ethnoconstructivism, 3D Page Flip

\section{Introduction}

Education is a processing effort carried out by someone to gain knowledge, skills, and habits in life. [1] Education is a very important activity, with human education can change behavior and knowledge for the better. In Indonesia education is always an interesting thing to discuss. Starting from the education system, curriculum, facilities, teacher competencies, student delinquency, to global influences. [2] There are three main priorities: increasing equality and access, improving the quality and relevance, and approval and accountability of management. According to Law No. 16 of 2007 point 1 that teachers must understand the characteristics of students from physical, moral, social, cultural, emotional and intellectual aspects [3]. This shows that in implementing learning the teacher must integrate the cultural values and socio-cultural background of the students. The learning goal that integrates cultural values and local wisdom around students is to ensure students know the cultural values and local wisdom that are around them and students can maintain and preserve those values from cultural attacks from other countries. Students can have a love for their culture and not lose their identity as a nation. Noble values, customs, and culture can encourage students to have a sense of pride and become a foundation for students to act in their daily lives. These very diverse values must be utilized by the teacher as a learning resource [4].

Currently, education in Indonesia is much influenced by the industrial revolution 4.0, namely technology, information and communication (ICT). The progress of information and communication technology has transformed the teaching and learning process towards a portable, student-centered and multi-platform environment [5]. Changes and technological advancements in various fields, for example in communication and information technology today [6]. Therefore, the development of information and communication technology is needed. The development of information and communication technology can be used to support and develop children's cognitive, affective and social skills [7]. This interaction is made easily accessible using mobile devices alongside social media, a free web tool that can improve learning [8]. However, globalization forces the entry of outside culture into Indonesian society. This is worrying about the loss of Indonesian native culture as a national identity, even though digital education has been recognized as having a profound impact on learning procedures $[9,10]$. Here the teacher has a very vital role, where the teacher must be able to be a filter for the real culture that goes into students' thinking. The teacher must be able to process the development of ICT in a positive direction so that students do not forget their original culture as the Indonesian nation. Actually the purpose of learning is to link the values of local wisdom around the students themselves, so that students know the value of local wisdom around them and it is hoped that students will be able to maintain and 
preserve the value of local wisdom so that it still exists and is not displaced by outside culture and students remain rests on the values of local cultural wisdom in the area around students as reinforcing the character of students so as not to lose identity. Like stories from the region from the area where students live can encourage students to be able to maintain the values of local cultural wisdom by knowing and maintaining good values that can be the basis of the character of students in the area where they live. Cultural values or ethno, in fact, must be implemented in learning, as a reinforcement of students' character.

The teacher is as an organizer of a learning environment and as a learning facilitator, as a model, planner, fortune teller, leader, and as a guide to the direction or direction towards learning centers [11]. Teachers, in order to be able to create an active and pleasant atmosphere in the learning process, can utilize technology, wherein the 21 st Century today teachers cannot only use teaching methods like in the past that only used a printed book and used the lecture method until the end of the learning process. This research is a teacher who makes great activation in his roles in the classroom and is the most important factor that improves classroom management and enriches learners' knowledge [12]. Teachers can use technology in the learning process by using learning media in the form of audio-visual, visual, video. [13] The use of multimedia may encourage students to work in groups, express their knowledge in multiple ways, solve the problem, improve their own work, and construct knowledge. Media is a teacher's tool in conveying material that will be delivered to students in the learning process. The development of advances in information technology and communication in the Industrial Revolution 4.0 has had a major influence on aspects of life including the world of education [14]. The implementation of the 2013 curriculum emphasizes the use of Information Technology as a medium of learning and assessment. Learning and assessment must be in line with technological developments that have penetrated the world of education. History Information technology itself comes from the world of education. Sophisticated and IT-based learning media is a form of concrete evidence that the world of education is inseparable from IT development [15]. So from that, the teacher must use IT in learning as well as in the assessment, this has been done, but few still use it in the era of industrial revolution 4.0. It can also have a positive impact on the interest in digital literacy in reading because there are still a few who use digital literacy in reading low. This is indicated by the results of PISA reading performance which shows that Indonesia is ranked 45th [16]. Therefore we need electronic-based teaching and evaluation materials.

When using electronic-based teaching and assessment materials, those who apply them (the teacher) must be able to master them. The involvement of mobile devices in education realm has begun with the birth and invasion of ICT in the educational arena, the use of information and communication technologies in education has undergone several paradigm shifts over the period since the launch of microcomputers in schools in $1981[17,8]$. However, the teacher's skills in using ICT, especially elementary school teachers can be said to be still low. [18] Teachers of traditional teaching methods "dictation notes" have proven remarkable in teaching and learning. This can be caused by teachers not understanding about ICTs, lack of training or due to lack of available facilities. [19] Technology adds value to education and supports more effective pedagogy by providing knowledge to students and improving communication that supports learning. In the development of globalization that is very heavy as currently teachers are required to master ICT well. Technology should have been applied in education in Indonesia. One of the objectives of the application of ICT in education is to improve the quality and quantity of education and teachers in Indonesia. [20] ICTs make knowledge acquisition more accessible, and in the field of learning, involving students in the application of ICTs. There are many things that teachers can do by using Tats in the learning process. Teachers can find more educational references, teachers can use ICT as a learning medium. [21] This method provides confidence and motivation that increases learning. Education and culture are two things that cannot be separated. Therefore, the teacher must be able to teach students to use ICT without leaving the cultural values of students, technology-based learning and assessment or E-learning and E-Assessment is one of the things that can be used by teachers in the learning process.

ICT in the industrial revolution 4.0 influences approaches in learning. Wireless technology on mobile devices (smartphones or tablets) has changed the teaching and education approach [22]. [23] E-learning and online courses refer to courses that are delivered in part or in full online, synchronously or out of sync. By using e-learning, students will become more motivated in learning. [24] Content that can be enjoyed more easily and whatever is available can use learning resources effectively or can activate the content itself at home or school. E-learning model and the growth of the provision of formats (virtual learning environments, bookstores, blended, mobile and others) demands a knowledge set that is still under construction [25]. In addition, e-learning will make it easier for teachers to deliver subject matter. One form of e-learning based learning is to use the 3D page flip book application. E-books are innovative books designed to produce printed books because they produce products in the form of soft and economical distribution files. [26]; [27]; [28]; [29] The ethnoconstructivism module developed here will use professional 3D flip pages.

The purpose of responding to ethnoconstructivism-based e-module implementations using flip-page 3D. In this study, the research questions are as follows: 
1. How does the students and teacher's response to e-modules based ethnoconstructivism?

2. Is there a difference between using ethnoconstructivsm-based e-modules using a conventional 3D flip page?

\section{Materials and Methods}

This study was adopted from research [30]. It was Developed development stage, Implication and Evaluate (evaluation stage). The development carried out the stage of developing and making e-modules based on the flowchart and storyboard [31]; [32]. The material used is ethnocontructivism-based e-modules that use 3D Page Flip in grade 5 elementary schools with Clean Air for Health material.

1. The Development Phase, this stage is the stage of developing an E-module which contains ethnocontuctivsm-based fifth-grade lessons. At the development stage, the available fifth-grade lesson modules were then made into 3D Page-based 3D software design rules. The development of e-modules is validated by experts to test product validity and the final results of the e-module development process are the e-module design that will be implemented in the next process.

2. At the implementation stage, ethnocontuctivsm-based e-modules for the fifth grade base use the 3D Page application that has been prepared and implemented in accordance with its role and function as an e-learning that can facilitate learning and research in the fifth grade with hope that system users can use it well and can improve the understanding of fifth grade students that will be delivered and reviewed by the teacher. In addition, the use of ethnocontructivsm-based e-modules using 3D Page flip can facilitate students in terms of mobile-based use and can be carried everywhere without having to carry fifth-grade lesson modules and printed modules. The final result of the implementation process is ethnocontructivsm based learning module problem solving and fifth-grade using 3D Page flip of elementary school.

3. In the evaluation phase, the process carried out was to see students' interest in using fifth-grade e-modules using the 3D Page flip.

This research on development, implementation, and evaluation used was adopted from [30]. The research sample consisted of 88 fifth-grade students who were in SD 13 and SD 14 Batanghari. At SD 13 there were experimental classes and the control class was 43 students. At SD 14 there are 45 experimental students and control classes. In the experimental class using ethnoconstructivsm-based e-modules using flip 3D pages and control classes using conventional textbooks belonging to students. The instruments used in this study were teacher's questionnaire responses to e-modules. The ethnoconstructivism e-module has been through a trial phase conducted by several experts and is declared good. Teacher response questionnaires for ethnoconstructivism-based e-modules using 3D Page flip in table 1:

Table 1. Categorized teacher and students responses to e-modules

\begin{tabular}{|c|c|}
\hline \multicolumn{2}{|c|}{ Respond E-Modul } \\
\hline Interval & Category \\
\hline $20.0-36.0$ & Very Not Good \\
\hline $36.1-52.0$ & Not Good \\
\hline $42.1-68.0$ & Enough \\
\hline $58.1-84.0$ & Good \\
\hline $64.1-100.0$ & Very Good \\
\hline
\end{tabular}

Responses students after using e-modul based ethnoconstructivism in students responses, then analyzed using inferential statistics with t-test (Independent sample t-test) with the help of SPSS 21 computer program.

\section{Results and Discuss}

\subsection{Results}

The results of the research conducted by this researcher are modifications to fifth-grade lesson modules based on ethnoconstructivism that use the 3D Page flip application. This renewal is modifying by researchers formed in creating and implementing ethnoconstructivism based e-modules using 3D Page flip. The results of the implementation ethnoconstructivism-based e-modules using 3D Page Flip. There is a combination of the use of ethnoconstructivism e-modules.

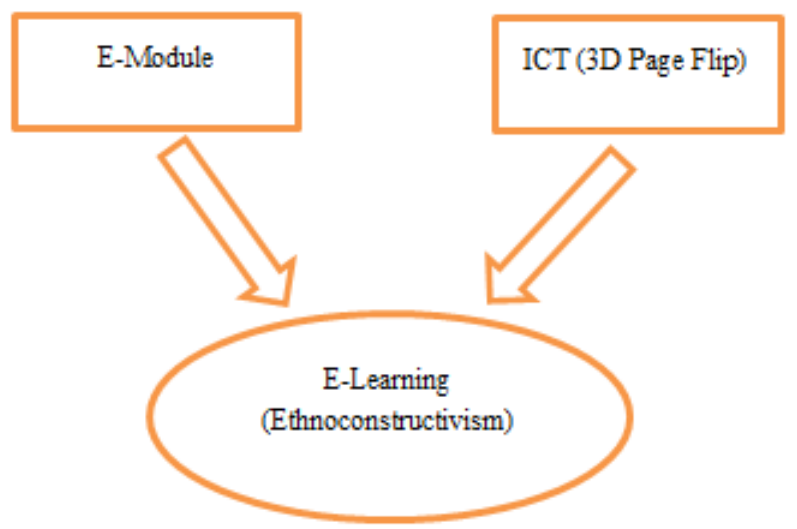

Figure 1. Diagram Relation of Learning Ethnoconstructivsm

Researchers conduct learning activities based on the context of the current curriculum implementation (K-13), which uses local wisdom as a source of learning. In the industrial revolution era, 4.0 local wisdom-based learning must use ICT (flip 3D pages) so that the implementation of 
the process results in the ethnoconstructivism e-module.

The module created is a learning module by incorporating cultural values that are around students. Integration of local cultural values in the module is so that students more easily understand learning material. The making of this module uses a constructivist learning approach, so this module is called the ethnoconstructivism module. [43] The constructivist learning processes support students' active participation, knowledge construction, and deep learning, encourage students to think and act independently, and foster permanent learning.

The ethnoconstructivism module is a module that contains learning material where the material is seen in terms of culture. This ethnoconstructivism module is then developed using a professional 3D page flip application. The development of ethnoconstructivism modules into professional 3D page applications is a form of e-learning development so students are more interested in learning.

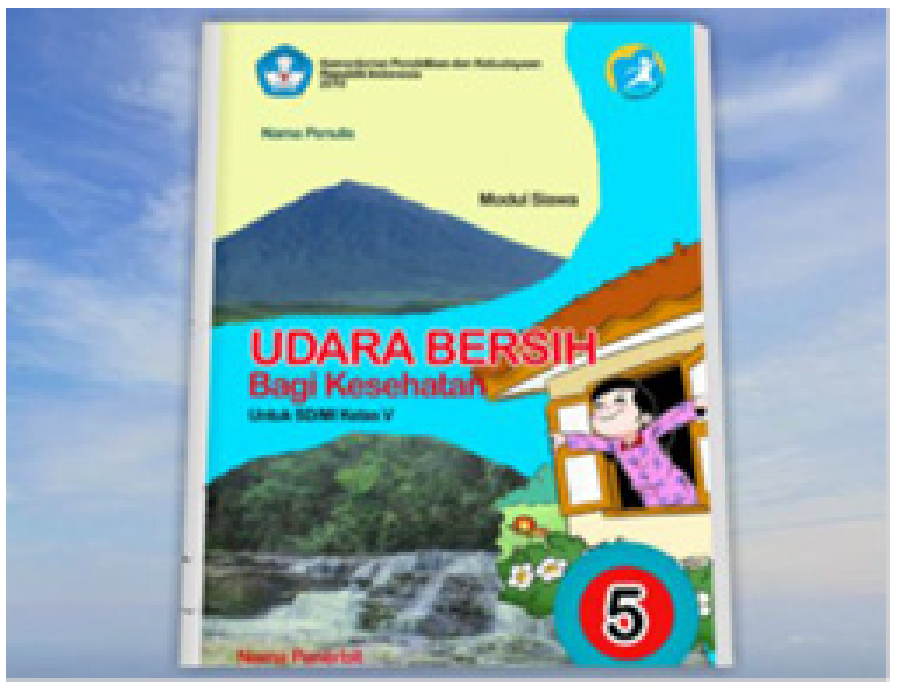

Figure 2. Cover of the flip ethnoconstructivism e-module 3D page

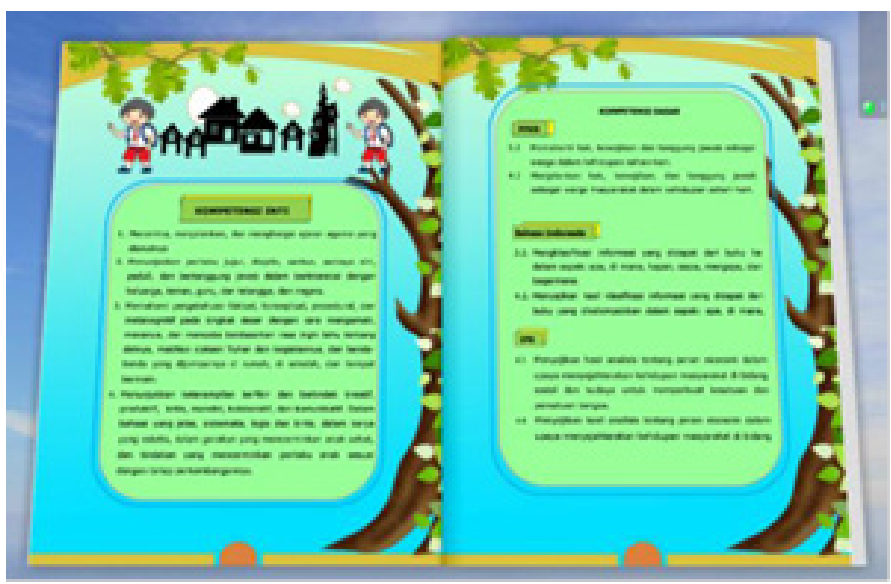

Figure 3. Core and Basic Competency Pages view the 3D page of the ethnoconstructivism e-module flip 


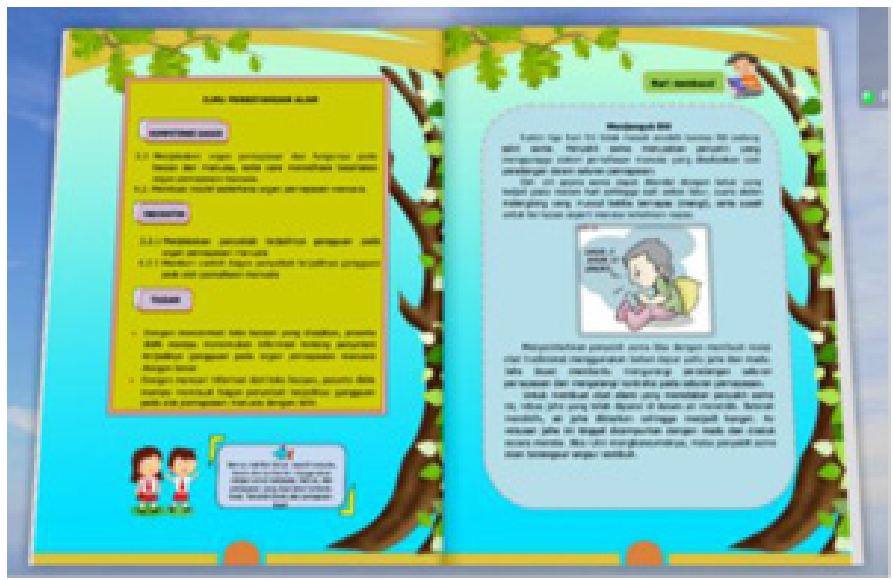

Figure 4. Indicator Pages and Learning Objectives the 3D page flip the ethnoconstructivism e-module

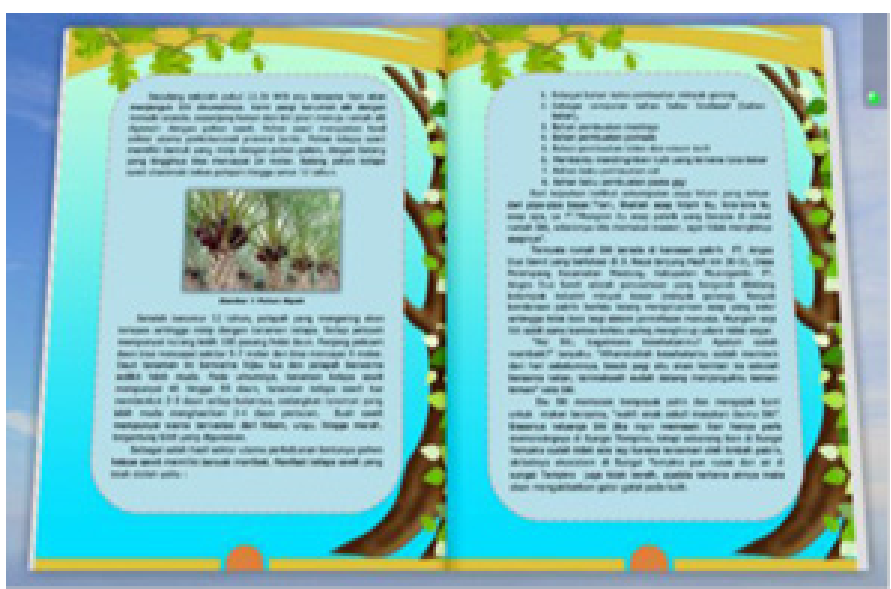

Figure 5. 3D page story page for the ethnoconstructivism e-module flip

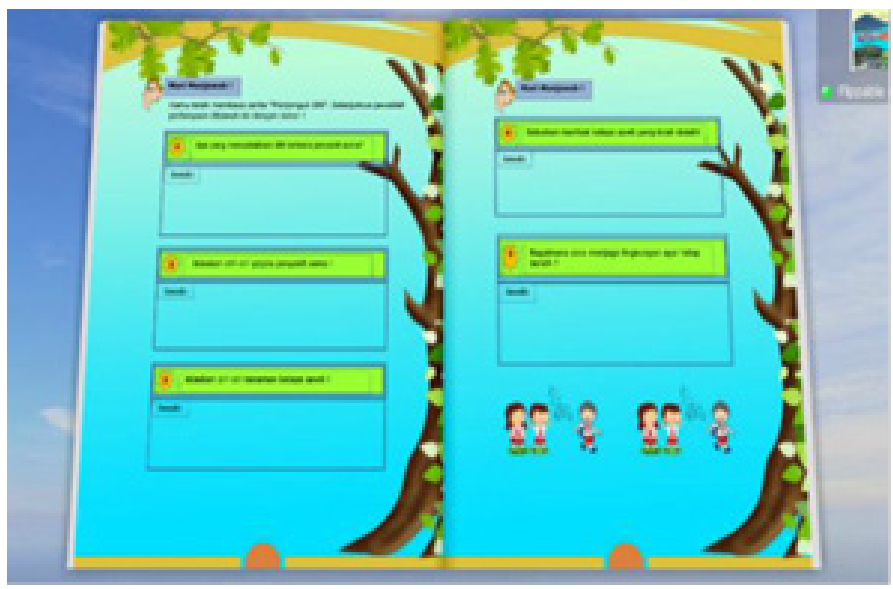

Figure 6. 3D page question for the ethnoconstructivism e-module flip 


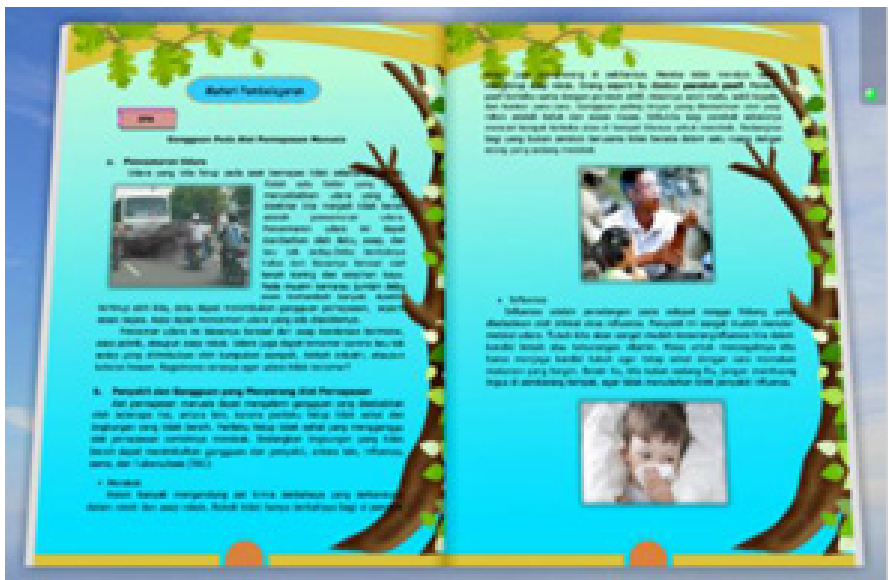

Figure 7. Flip ethnoconstructivism e-module 3D page material

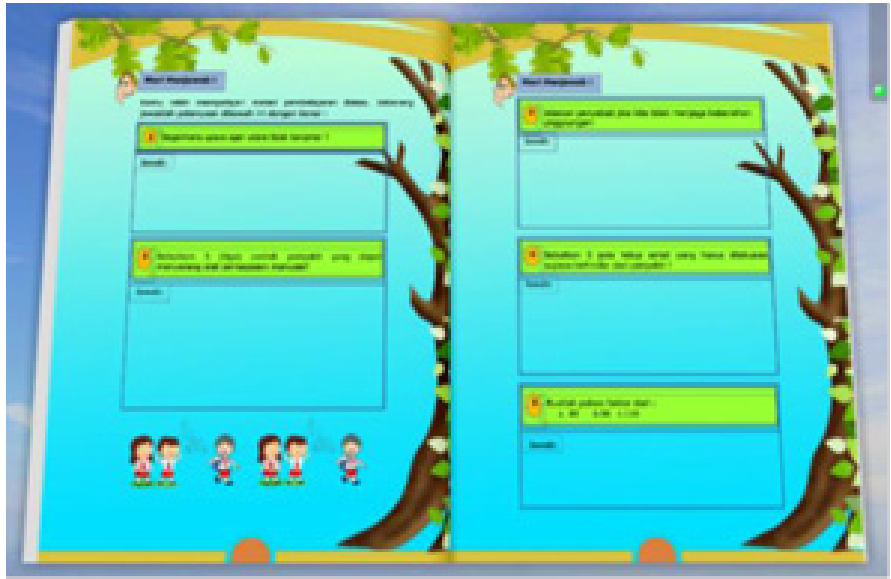

Figure 8. 3D page flip page for the ethnoconstructivism e-module

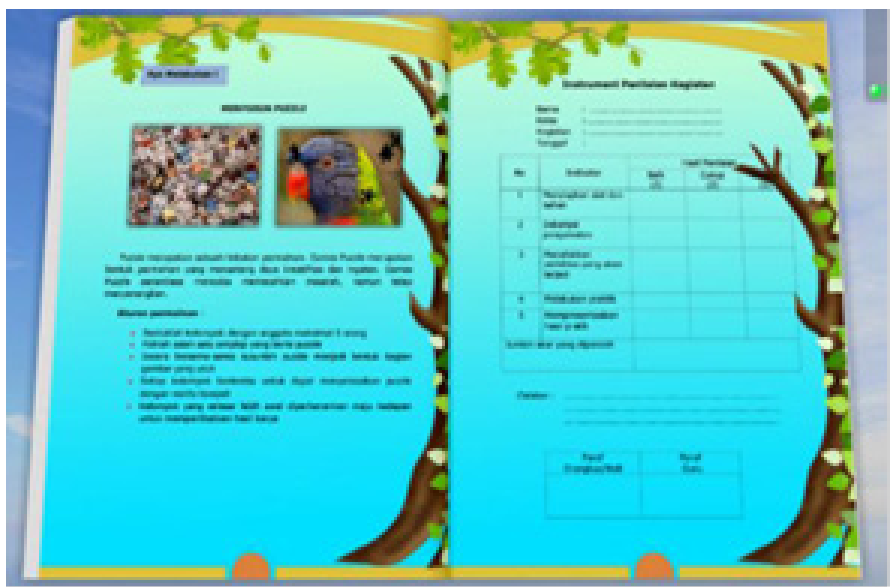

Figure 9. Crafting pages and activity assessment instruments using the $3 \mathrm{D}$ ethnoconstructivism module flip page

After the development of the ethnoconstructvism module using 3D page flip was completed, a demonstration was held to elementary school students.

From the demonstration activities, the data obtained from students and teachers were as follows:

Based on table 2. In the control class the most dominant category is not good at $54.5 \%$ with 12 students from 22 total students, then very not good at $18.2 \%$ with 4 students from 22 total students, enough category at $18.2 \%$ from 4 students from a total of 22 students, and good at $9.1 \%$ from 2 students with a total of 22 students. The median values in the student responses are 42.0, the min value is 24.0 and the max value is 98 . Then the results in the experimental class, dominant is good category, which is equal to $60.7 \%$ with 
14 students from 23 total students, then is enough $17.4 \%$ category of 4 students out of a total of 23 students, very good category is $13.2 \%$ of 3 students of 23 total students, and not good is $8.7 \%$ of 2 students out of a total of 23 students. The median values of student responses are 76.0, the min value is 38.0 and the max value is 99.0 .

Based on table 3. Respond teacher to e-module has the most dominant category, which is good at $42.9 \%$ with 6 teachers from 14 total teachers, then that is enough at $28.6 \%$ from 4 teachers from a total of 14 teachers, very good at $21.5 \%$ from 3 teachers with a total of 14 teachers, and not good at $7.1 \%$ with 1 teacher from 14 total teachers. The median values in the results of teacher responses to e-modules are 70.0, min value is 51.0 and max value 95 . Then the teacher's response to dominant e-interests is a good category, which is equal to $57.1 \%$ with 8 teachers from 14 total teachers, then is enough category $21.5 \%$ of 3 teachers from a total of 14 teachers, very good category is $14.3 \%$ of 2 teachers of 14 total teachers, and not good is $7.1 \%$ of 1 teacher of a total of 14 teachers. The median values are in the results of the teacher's response to e-interests is 72.0 , min value is 50 and max value 96 .

Table 2. Results of student interest in SD 14 control class and SD 14 expedition class

\begin{tabular}{|c|c|c|c|c|c|c|c|}
\hline \multirow{8}{*}{ Class Control } & \multicolumn{3}{|c|}{ Category } & \multirow{2}{*}{ Median } & \multirow{2}{*}{ Min } & \multirow{2}{*}{ Max } & \multirow{2}{*}{$\%$} \\
\hline & Interval & Attitude & Total & & & & \\
\hline & $20.0-36.0$ & Very Not Good & 4 & \multirow{5}{*}{42.0} & \multirow{5}{*}{24} & \multirow{5}{*}{98} & 18.2 \\
\hline & $36.1-52.0$ & Not Good & 12 & & & & 54.5 \\
\hline & $52.1-68.0$ & Enough & 4 & & & & 18.2 \\
\hline & $68.1-84.0$ & Good & 2 & & & & 9.1 \\
\hline & $84.1-100.0$ & Very Good & 0 & & & & 0 \\
\hline & \multicolumn{2}{|c|}{ TOTAL } & 22 & & & & 100 \\
\hline \multirow{8}{*}{$\begin{array}{c}\text { Class } \\
\text { Experiment }\end{array}$} & \multicolumn{3}{|c|}{ Category } & \multirow{2}{*}{ Median } & \multirow{2}{*}{ Min } & \multirow{2}{*}{ Max } & \multirow{2}{*}{$\%$} \\
\hline & Interval & Attitude & Total & & & & \\
\hline & $20.0-36.0$ & Very Not Good & 0 & \multirow{5}{*}{76.0} & \multirow{5}{*}{38} & \multirow{5}{*}{99} & 0 \\
\hline & $36.1-52.0$ & Not Good & 2 & & & & 8.7 \\
\hline & $52.1-68.0$ & Enough & 4 & & & & 17.4 \\
\hline & $68.1-84.0$ & Good & 14 & & & & 60.7 \\
\hline & $84.1-100.0$ & Very Good & 3 & & & & 13.2 \\
\hline & \multicolumn{2}{|c|}{ TOTAL } & 23 & & & & 100 \\
\hline
\end{tabular}

Table 3. The results of Teacher's Respond to e-modules

\begin{tabular}{|c|c|c|c|c|c|c|c|}
\hline \multirow{8}{*}{ e-module } & \multicolumn{3}{|c|}{ Category } & \multirow{2}{*}{ Median } & \multirow{2}{*}{ Min } & \multirow{2}{*}{ Max } & \multirow{2}{*}{$\%$} \\
\hline & Interval & Attitude & Total & & & & \\
\hline & $20.0-36.0$ & Very Not Good & 0 & \multirow{5}{*}{70.0} & \multirow{5}{*}{51} & \multirow{5}{*}{95} & 0 \\
\hline & $36.1-52.0$ & Not Good & 1 & & & & 7.1 \\
\hline & $52.1-68.0$ & Enough & 4 & & & & 28.6 \\
\hline & $68.1-84.0$ & Good & 6 & & & & 42.9 \\
\hline & $84.1-100.0$ & Very Good & 3 & & & & 21.5 \\
\hline & \multicolumn{2}{|c|}{ TOTAL } & 14 & & & & 100 \\
\hline
\end{tabular}

Table 4. Independent sample t-test

\begin{tabular}{|c|c|c|c|c|c|c|}
\hline & \multirow{2}{*}{$\mathrm{T}$} & \multirow{2}{*}{ df } & \multirow{2}{*}{ Mean } & \multirow{2}{*}{ Std.Deviation } & \multicolumn{2}{|c|}{ 95\% confidence interval } \\
\hline & & & & & Lower & Upper \\
\hline \multirow{2}{*}{ Student response in e-modules } & 18.342 & 88 & 3.0906 & .14321 & 18.234 & .6120 \\
\hline & 18.342 & 128.067 & 2.2033 & .20015 & 17.985 & .8615 \\
\hline
\end{tabular}


Based on the results of the questionnaire sheet of interest students after using e-module class five lessons based on ethnoconstructivism using the 3D page application analyzed using inferential statistics from the SPSS 21 program. The hypothesis test was carried out using the independent sample t-test. The results of the analysis using the test are presented in the table 4 .

From table 4 it can be seen that the value is obtained $(t$ count) with $t$ table values. The value of the table can be found in Table 4: the significance of 0.025 (2-sided test) with degrees of freedom (df) 88. In this study, the results for $t$ table are 1.97658. While for the value of $t$ the count can be seen in table 6. (column $t$ ) which is 18,342 . The hypothesis testing criteria is the value of $t$ count is there is a rejection of $\mathrm{H}_{0}$ [42]. So, it can be concluded that there is a significant difference in student responed between grade 5 students SD 13 and SD 14 using 3D Page flip based ethnoconstructivism e-modules and not using the 3D Page-based ethnoconstructivism 3D e-module. Can be seen from table 4 that the average value of student response is 3.0906, which means that the use of e-modules can student responses.

\subsection{Discussion}

Based on table 2 and 3, we can see that students' and teachers have a good response to e-modules used, this is indicated by a percentage of $42.9 \%$ for e-modules. However, there are also those who disagree as indicated by a percentage of $7.1 \%$ for e-modules. This is in accordance with the results of interviews conducted that young teachers are easier to operate computers than older teachers who have difficulty in operating the computer. [34]; [45]; [36] This is due to a lack of trust in their subject knowledge compared to their ICT knowledge and skills. However, most teacher responses to both ethnoconstructivism-based e-modules use 3D Page flip and e-interest.

In addition, interviews were also conducted with students about the use of e-modules, the results of the interview were as follows:

"We are very happy to learn to use ethnoconstructivism-based e-modules using $3 D$ page flip from conventional books because the appearance of e-modules is very interesting" (student interview, 18 April 2019).

"I like learning with computers, I have never been invited to learn to use a computer before. The lessons are also easy" (student interview, 18 April 2019).

"Learning is fun, I and my friends like to learn to use laptops rather than using conventional books. It's just that there is no laptop at home, so it's difficult to study at home" (student interview, April 19, 2019).

From the results of interviews, students tend to respond well when asked about ethnoconstructivism-based e-modules using 3D page flip. Students are very enthusiastic and very interested in using technology in learning activities rather than using conventional books.

Then the response from teachers to e-modules is quite good, this can be seen from the results of interviews that have been conducted, namely:

"This E-Module is very good, very helpful in learning, because as we see students are very happy. Students really enjoy learning to use a laptop or ethnoconstructivism-based e-module using flip $3 D$ pages. If all modules are like this, I am sure the child's interest in learning will definitely improve"(teacher interview, 18 April 2019).

"The E-Module is good, the contents are good, it matches the Core Competencies and Basic Competencies. E-Modules are also good because they elevate the local culture of the surrounding community so that children are easier to understand the material being taught". (teacher interview, 18 April 2019).

"The interest used in measuring student interest is very helpful for teachers and assessing students in learning, because teachers do not have to worry about losing or losing their assessment, with e-interest using this SESKA system, teachers do not have to worry about loss and loss of data. Their assessment, because the teacher can operate it through a computer or smartphone (teacher interview, 19 April 2019).

Seeing the teacher's response to ethnoconstructivism-based e-modules using 3D page flip tends to be good. E-Modules are considered to be in line with core competencies and basic competencies. And also e-modules can be easily carried anywhere. In addition to e-modules, teachers also agree on e-interests that are used to measure student interest in learning, due to the security that make the teacher like it.

Based on data obtained from the implementation of the e-module based on 3D Page flip ethnoconstructivism, it can be seen that the use of e-modules is effective in increasing students' abilities and interests. This is based on e-module which is part of e-learning, where the use of e-learning in learning makes the learning process can be carried out continuously. Besides that E-learning is a solution in offering various possibilities for social networking so that in this way the teacher can store various records of student interaction in collaborative learning [37].

Through learning to use products from information and communication technology various multimedia services can be easily transferred, such as high-resolution audio, video, graphics so that the thought process can lead to thinking. Added also the advantage of using e-learning is that students can interact not only in two directions but can be multi-purpose. Where to improve students' abilities and interests through e-modules, where the use of e-modules uses media such as computers/laptops, events that make smartphone students interested and motivated [38]. [39] Mobile learning is most effective when its three aspects (learner, device and social) are all fulfilled in the learning 
process. [40]; [41] developed a personalised mobile learning system to support guided-inquiry learning activities for secondary school students. They found that students' learning achievements and attitude were significantly improved. Judging from the results obtained that the teacher has a good response to the use of ethnoconstructivism e-modules that can facilitate the teacher in teaching, and make students more interested in learning. Therefore, researchers recommend the use of ICT or learning and assessment based on electronics and oriented to local wisdom so that it can be applied.

\section{Conclusions}

It can be seen that the response from teachers to ethnoconstructivism-based e-modules is in the good category. On the interest results for the control class that uses conventional there are significant differences with the experimental class using ethnoconstructivism-based e-modules using flip-page $3 \mathrm{D}$, which is in the superior experimental class because it uses ethnoconstructivism-based e-modules using flip 3D pages.

\section{Acknowledgements}

The researcher expressed his gratitude to all elementary school teachers in Batanghari District, Muaro Jambi Regency and Jambi City for their participation and cooperation. The researcher also thanked the Education Office of Batanghari Regency, Muaro Jambi Regency and Jambi City for their support and cooperation. This research is funded by superior tertiary applied research grants from the Directorate General of strengthening research and Development of the Indonesian Ministry of Research, Technology and Higher Education (Ristekdikti) with Jambi universities through contract number $060 /$ SP2H / LT / DRPM / 2019 dated December 052018.

\section{REFERENCES}

[1] Astalini, Kurniawan, D. A., Perdana, R., \& Pathoni, H. (2019). Characteristic of Students' Attitude to Physics in Muaro Jambi High School. Humanities \& Social Science Research. 7(2). 91-99. https://doi.org/1018510/hssr.2019.7 210

[2] Firman, H \& Tola, B. (2008). "The Future of Schooling in Indonesia". Journal of International Cooperation in Education, 11(1), pp.71-84

[3] The Republic of Indonesia. (2007). Minister of National Education Regulation No. 16 of 2007 concerning Academic Qualification Standards and Teacher Competencies. Jakarta: State Secretariat.
[4] Goode, J.P., \& Stroup, D.R. (2011). Everyday nationalism: Constructivism for the mass. Social Science Quarterly, 96(3), 717-739. 2015.

[5] Idris, N., Hashim, S. T. Z., Samsudin, R., \& Ahmad. N. B. (2017). Intelligent Learning Model based on Significant Weight of Domain Knowledge Concept for Adaptive E-Learning. International Journal on Advance Science Engineering Information Technology. 7(4). pp: 1486-1491.

[6] Ambiyar., Yondri, S., Irfan, D., Putri, M, U., Zaus, M, A., Islami, S. (2019). Evaluation of Packet Tracer Application Effectiveness in Computer Design Networking Subject. International Journal on Advance Science Engineering Information Technology. 9(1). pp: 54-59.

[7] Kraleva, R., \& Kralev, V. (2018) An Evaluation of The Mobile Apps for Children with Special Education Needs Based on The Utility Function Metrics. International Journal on Advance Science Engineering Information Technology. 8(6). pp. 2269-2277.

[8] Chee, K.N., Yahaya, N. and Ibrahim, N. H. (2018). 'Factors of students' performance based on cognitive level in a mobile learning environment', Int. J. Mobile Learning and Organisation, 12(2), pp.190-212.

[9] Shin, N., Sutherland, L.M., Norris, C.A. and Soloway, E. (2012). 'Effects of game technology on elementary student learning in mathematics', British Journal of Educational Technology, 43(4), pp.540-560.

[10] Komalawardhana, N. and Panjaburee, P. (2018) 'Proposal of personalised mobile game from inquiry-based learning activities perspective: relationships among genders, learning styles, perceptions, and learning interest', Int. J. Mobile Learning and Organisation, 12(1), pp.55-76.

[11] Zein, M. (2006). Peran Guru Dalam Pengembangan Pembelajaran. Inspiratif Pendidikan, 5(2), 274-285. DOI: https://doi.org/10.24252/ip.v5i2.3480

[12] Abdel Rahman Ibrahim, M. H. (2016). Classroom Management The Effectiveness of Teacher's Roles. Education and Linguistics Research, 2(1). https://doi.org/1 0.5296/elr.v2i1.9053

[13] Rasyid, M. A., Ampa, A. T., Rahman, M. A., \& Basri, M. (2013) The Implementation of Multimedia Learning Materials in Teaching English Speaking Skills. International Journal of English Language Education, 1(3), pp.294-304. DOI:10.5296/ijele.v1i3.4153

[14] Astalini, A., Kurniawan, D. A., Sulistiyo, U., Perdana, R., \& Susbiyanto, S. (2019). E-Assessment Motivation in Physics subjects for Senior High School. International Journal of Online and Biomedical Engineering (iJOE), 15(11), 4-15.

[15] Manongga, D., Tambotoh, J. J. C., \& Bawu, J. N. (2009). Perancangan Modul Pembelajaran Berbasis Interactive Multimedia Learning. Jurnal Teknologi Informasi-Aiti, 6(1), 16-29.

[16] OECD (2019), Reading performance (PISA) (indicator). Doi: 10.1787/79913c69-en (Accessed on 14 May 2019).

[17] Wellington, J. (2005). 'Has ICT come of age? Recurring debates on the role of ICT in education, 1982-2004', Research in Science \& Technological Education, 23(1), pp.25-39. 
[18] Jadhav, V. (2011) "ICT and Teacher Education". International Educational E-Journal, 1(1), pp. 64-69.

[19] Bakar, R. \& Mohamed, S. (2008). "Teaching using information and communication technology: Do trainee teachers have the confidence?" International Journal of Education and Development using Information and Communication Technology (IJEDICT), Vol, 4, No, 1, pp. $5-12$.

[20] Fu, J.S. (2013). "ICT in Education: A Critical Literature Review and Its Implications". International Journal of Education and Development using Information and Communication Technology (IJEDICT), 9(1), pp. 112-125.

[21] Bansal, D. (2016). "Benefits of ICT in Education". Bhartiyam International Journal of Education \& Research. $5(2)$.

[22] Junrat, J., Srisawasdi, N. and Saikaew, K.R. (2019) 'The effect of using a semi-automated image processing mobile application on undergrad students' perception in a complex science experiment', Int. J. Mobile Learning and Organisation, 13(2), pp.193-216.

[23] Lister, M. (2014) "Trends in the Design of E-Learning and Online Learning”. MERLOT Journal of Online Learning and Teaching. 10(4)

[24] Kaewkiriya, T. (2013) “A Design And Development Of E-Learning Content For Multimedia Technology Using Multimedia Game". International Journal of Software Engineering \& Applications (IJSEA), 4(6).

[25] Mello, G.L.S., Abbad, G.S. and Montezano, L. (2018) 'Reasons and attributes for the use of mobile learning in a Brazilian financial institution', Int. J. Mobile Learning and Organisation, 12(4), pp.353-372.

[26] Raihan, S. Haryono. \& Rahmadi, F. (2018). "E-Book Development, Scientific Learning Using the 3D Professional Pageflip Program". Innovative Journal of Curriculum and Educational Technology. 7(1). pp. 7-14.

[27] Yank, K. (2009). Build Your Own Database Driven Web Site Using Php \& Mysql. Australia: Sitepoint.

[28] Niyizamwiyitira, C.dan Lundberg, L. (2017). Performance Evaluation of Sql and NoSQL Database Management Systems in a Cluster. International Journal of Database Management Systems (IJDMS). 6(9). pp. 1-24.

[29] Sutopo, H. (2012). Pengembangan Evaluasi Pembelajaran Berbasis Multimedia Dengan Flash, Php, Dan Mysql. Jurnal Informatika. 1(11). pp. 1-7. DOI: https://doi.org/10.9744/in formatika.10.2.79-85

[30] Permadi, T., \& Mustangin, M. (2015). Pengembangan Attitude E-Assessment Pada Pembelajaran Matematika Sekolah Menengah Atas. JPM: Jurnal Pendidikan Matematika, 1(2), pp. 118-126.

[31] Branch, R. M. (2009). Instructional design: The ADDIE approach (Vol. 722). Springer Science \& Business Media.

[32] Ivers, K. S., \& Barron, A. E. (2002) Multimedia Project in Education: Designing, Producing, and Assessing. USA: Libraries Unlimited.

[33] Sitotaw, Belay and Kumneger Tadele. (2016). Student Attitude toward Physics in Primary and Secondary Schools of Dire Dawa City Administration, Ethiopia. World Journal of Educational Research and Reviews. 2(2), pp 014-021.

[34] Ariawan, B., Muhsetyo, G., \& Qohar, A. (2017) Pengembangan Edutainment Multimedia untuk Meningkatkan Interest dan Hasil Belajar Program Linier Siswa Smk. Jurnal Pendidikan: Teori, Penelitian, dan Pengembangan, 2(6), 780-789.

[35] Nurhasanah, S., \& Sobandi, A. (2016). Interest belajar sebagai determinan hasil belajar siswa. Jurnal pendidikan manajemen perkantoran, 1(1), pp. 135-142.

[36] Morley, G. (2011). "Primary Teachers, and ICT: Is gender, age or experience important?" Systemics, Cybernetics, and Informatics. 9(7).

[37] Colak, E. (2017). “Teachers' Experiences in a Professional Learning Community on the Constructivist Lesson Planning: A Case Study among Primary School Teachers". Education and Science. 42(190).

[38] Martínez-Caro, E., Cegarra-Navarro, J. G., \& Cepeda-Carrión, G. (2015) An application of the performance-evaluation model for e-learning quality in higher education. Total Quality Management \& Business Excellence, 26(5-6), 632-647.

[39] Li, K.C., Lee, L.Y-K., Wong, S-L., Yau, I.S-Y. and Wong, B.T-M. (2019) 'The effects of mobile learning for nursing students: an integrative evaluation of learning process, learning motivation, and study performance', Int. J. Mobile Learning and Organisation, 13(1), pp.51-67.

[40] Wongwatkit, G., Panjaburee, P. and Srisawasdi, N. (2017). 'A proposal to develop a guided-inquiry mobile learning with a mastery learning mechanism for improving students' learning performance and attitudes in Physics', Int J. Mobile Learning and Organisation, 11(1), pp.63-86.

[41] Zheng, L., Li, X., Tian, L. and Cui, P. (2018). 'The effectiveness of integrating mobile devices with inquiry-based learning on students' learning achievements: a meta-analysis', Int. J. Mobile Learning and Organisation, 12(1), pp.77-95.

[42] Cramer, D. (2003). Advanced quantitative data analysis. McGraw-Hill Education (UK).

[43] Nindy Apsari, A., \& Kustijono, R. (2017). Development of E-Book Using Kvisoft Flipbook Maker to Train Science Process Skill for Senior High School Students in Curriculum 2013. Inovasi Pendidikan Fisika, 6(3). 